\title{
IMPROVING SERVICE QUALITY OF CALL CENTER USING DMAIC METHOD AND SERVICE BLUEPRINT
}

\author{
Fino Wahyudi Abdul \\ Departement of Logistic Management, Faculty of Social Science and Management, Institute of \\ Social Science and Management STIAMi, Jakarta, Indonesia \\ fino@stiami.ac.id \\ Nining Purwatmini \\ Departement of Administration Management, Academic of Secretary and Management of Bina \\ Insani, Bekasi, Indonesia \\ purwa_atma@yahoo.com
}

\begin{abstract}
Customer satisfaction is an important factor to businesses, because it causes customers to constantly return to use the service. Customer satisfaction is also related to the quality of service received by the customer of the companys' products or services. The problem of PT OCI call center service quality happened at the first time a customer contacts the call center where waste of customer's waiting time is detected. Service quality improvement methods used in the analysis of the waste of customers' waiting time is the DMAIC and lean approach. Results showed that improvement is seen at the sigma level. The tools used are SIPOC, pareto diagram, CTQ, two proportion test, DOE, p-chart, and minitab software. Service blueprint analysis is used to analyze and discuss the relationship between service quality improvement using DMAIC in service process, points of contact with customers, and the evidence seen by the customer service.
\end{abstract}

Keywords: Service Quality, Lean, DMAIC, Service Blueprint, Sigma Level

\section{Research Background}

One way to increase companies value that is perceived by its customers is through building good relationship. For example, a company offers prime quality product with competitive prices. These are the two things that attract customers to approach and finally buy the companies products. But sometimes customers feel that the company doesn't want anything to do with them when problems occur after purchase, or when the company needs time to find a way to build relationship with the customers. A call center division acts as a company's representative that posses direct contact with those customers. This is the reason why a call center has to have operators that really represents the company, then face to face contact by the customers. The main task of call center operators is to handle well all customers requests on the services offered by the company.

In many call centers, the operators have heavy responsibilities because they are under obligation to present high resolution work with low time period. When faced with this problem, many companies take steps by terminating their operators in order to increase productivity, hiring more operators without focusing on the main problem, or forcing their operators to be constantly in front of their telephone so they can increase result.

Laureani, Antony, and Douglas(2010) stressed that call center is a very important factor in increasing profit for any business, and that consistent emphasis will be on lowering cost but still giving best service. The opportunity to improve a call center is on the process of handling incoming telephone calls. It is where opportunities arise for the company to know more about its customers and have more interaction with them. Companies must choose the best way to 
meet customers expectation in answering their inquiries and handling their complaints, answering their questions, as well as giving solutions to their specific problems.

The quality of service is priority that is very important for a company who wants to give added value in their service within this tight and very competitive environment. In industrial countries, services area dominant sector in the country's economics where the products offered act only as a set of goods whereas services aim at understanding customers need (Nakhai \& Neves, 2009). Here, the opinion of customers become a guidance for service quality (Souza, He, Oliveira, Queiroz, \& Ambro, 2013).

George(2003) explained that the biggest lost a company can make is failing to consider and calculate potential lost of its customers. A company can lose anything related to earnings and costs. Time and workload management are essential needs in service function. A lot of people think that service applications have a setup time, but if the company needs a short time period to serve one customer after another, then it will need lots of time to reach normal productivity. This means that the company needs a setup time. On the other hand, each time the company delays service to a customer (internal or external) due to the fact that it is more comfortable to continue working, then the company is piling up workload to be managed later on (George, 2003).

PT OCI is a company in the field of service industry. Its product is health service and it has units in several big cities in Indonesia. One of its services to customers is a call center that functions as the source of information related to consumers' inquiries, complaints, and needs. Currently, PT OCI has branches in big cities such as Bandung, Semarang, Surabaya, Medan, Ujung Pandang, Bogor etc.

\section{Research Method}

Improvement of service quality at the call center uses a lean six method using "DMAIC methods" which focused on inbound center type of call center. Along side this methode, "service blueprint" tool is also used. According to Laureani (2011), references indicate that the benefit of lean six sigma in manufacture and services industries is to assure that service/product is in line with customer needs (VOC/Voice of Customer), to eliminate waste in critical business processes, to reduce defect, to shorten time cycle, and to voice the correct product/service at the right time and at the right place.

George (2003) stated that lean and six sigma have a "DMAIC methods" (Define, Measurement, Analysis, Improvement, Control). This "DMAIC method" significantly aids the improvement team to obtain a road map of quality improvement using tools that supports the accomplishment of every "DMAIC method phase". Atkinson (2014) added that the "DMAIC method" consists of five phases. The first one being D (Define), is a phase where main problems are defined and improvement is supported by the company. The second phase is $\mathrm{M}$ (Measurement) where evaluation is done to the operational performance and is used as a preliminary evaluation when evaluating solution such as decision of the sigma level. The third phase is A (Analysis) which is a phase where thoughts and analysis is done based on a measured problematic evidences and used as preliminary identification to the root problem and which has negative impact on the company's performance. The fourth phase is I (Improvement) is where data from the analysis phase is used to obtain improvement ideas and where implementation of change is needed for the fifth phase which is $\mathrm{C}$ (Control). The fifth phase is where steps to control result is defined and implemented to a remeasured performance result in order to obtain quality standard that is acceptable by the sigma level.

Mcadam, Davies, Keogh, and Finnegan (2009) indicates that "DMAIC methodology" on six sigma is a philosophy of business improvement to the companies strategy and operation. According to Riesenberger and Sousa (2010) through their research, although customer satisfaction is very important to a company, it is not easy to do in practice. "DMAIC methodology" on six sigma is used to manage customers complaints in the management 
process as long as several problems are defined, i.e variables influencing process are measured, causes of process failures are analyzed, improvement is planned and established, variables are controlled until the desired sigma level is reached, and optimization on highest customer satisfaction are obtained. According Kumar, Strandlund, and Thomas (2008) in their research, "DMAIC methods" at six sigma could be implemented upon designing service system before, during, and after interaction with customers by giving good service to customers which at the end will increase customers satisfaction, increase customer loyalty, and increase companies earnings. Dreachslinand Lee (2007) stated that although DMAIC at six sigma is a method commonly related to manufacture sector, it could effectively be used to increase strategy and management of various organizations. Antony, Bhuller, Kumar, Mendibiland Montgomery (2012) said that Communication and Information Management (CIM) is very important to a company, and that CIM effectiveness could result in significant improvement to the bottom line and customers satisfaction, and therefore the use of "DMAIC methods" could be implemented in this transactional case.

Lean six sigma is a management concept that combines methods from lean and six sigma, through the lean six sigma, a company can have the speed of lean and the quality of six sigma (Laureani, 2011). Antony et al. (2012) stated that company is a group of people that supports infrastructure services focused on the core competency of a company in providing high quality service of product. In this matter, lean six sigma provides management with concrete proofs to reach necessary decisions. This methodology is an important component in a companies cost management system. Lean arises from a 'just in time' concept and 'Toyota Production System' by eliminating waste and who focuses on customers, whereas six sigma focuses on giving value to customers (Debuks \& Debuks, 2010). Atkinson (2014) stated that improvement on companies performance could be reached with Lean Six Sigma Organization Development (LSSOD). LSSOD shows how Organization Development(OD) explains which culture and leadership style are appropriate to reach significant organizational change and improvement through the implementation of lean method and the use of six sigma ("DMAIC method") statistics that aims at improving and changing organization to be more successful.

Lean management defines companies aim in how it values its customers, plans it, and implements the flow and process of a value correctly in order to reach its objective, as well as keeping process in accordance with the human interface in problem solution (Jayaraman, 2010). Still according to Jayaraman (2010) lean method has been developed by Toyota to help standardize continuous improvement aiming at prompt and efficient production of pre ordered vehicles, known as the Toyota Production System (TPS). Gaspersz (2007) lean is defined as a systemic and systematic approach to identify and eliminate waste, to smoothen material, product and information flow, as well as to do continuous improvement. Liker (2006) indicates that TPS has identified seven wastes that has no added value such as overproduction, waiting, transportation, over-processing, inventory, motion, and defect.

Six sigma levels can be implemented in all processes, but implementing it to the accurate level will depend on the companies cost and benefit strategies. If a process has a 2 or 3 sigma levels at the beginning, it will be relatively easier to reach level sigma 4 , but to get to level 5 or 6 (six sigma), it would be need appropriate financial resources as well as sophisticated tools statistics (Souza, et al. 2013).

"Service blueprint" is a tool to show service process as well as points of contact with customers, and at the same time acts as part of customer satisfaction management. Chase (2004) points out that like in all other fields, the manufacture and service process design do need a flowchart. For this, service experts have created one and called it the service blueprint.

"Service blueprint" is crucially needed in a service process design Chase (2004) because service is intangible and difficult both to explain and to communicate. A service is given by an employee to a customer and results in varying outputs. The interaction line between customer and company is separated by a visible line. Figure 1 shows theflowchart service blueprint at PT 
OCI call center.

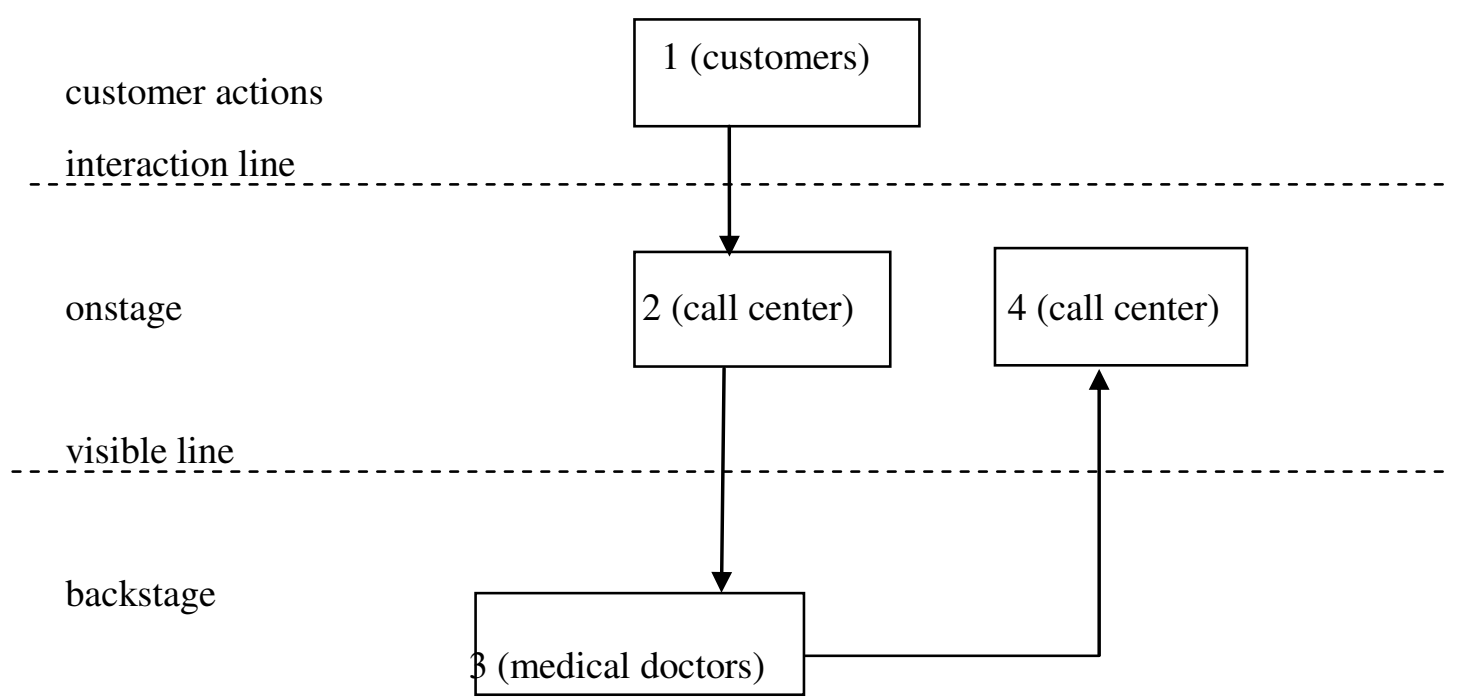

Figure 1 : Service blueprintatPT OCI call center

Service quality is an important priority for companies who want to see the difference of their services compared to those of their competitors in this current tight and competitive environment. For this, the "DMAIC methodology", where lean management is in, shall be combined generally with the service blueprint tool that shows service process, points of contact with customers, as well as evidences of the service seen by the customers.

\section{Result and Discussion}

\subsection{PT OC Call Center Data}

Here below is the data collected from PT OCI call center, during the year 2017 from January to December, there are 3000 numbers of calls received and of all those calls, there are 1290 numbers of defected calls, Table 1 shows what occurred during a time period of one year (12 months) in January until December 2015.

Table1 : Call center data received in one year (total number of calls per 2015)

\begin{tabular}{cc}
\hline Total number of calls received & 3000 \\
Total number of defected calls & 1290 \\
\hline Source : PT OCI
\end{tabular}

Source : PT OCI

Table 1 shows that there is an issue in call handling during the first call at PT OCI call center in form of defect. This surely influenced the quality of the call center.

\subsection{Analysis}

Based on data in Table 1, an analysis is needed in relation to the points and the quality of service of the problems. Analysis uses blueprint service methodology and DMAIC (Define, Measure, Analysis, Improve, Control - in this consecutive order). Defects occurring at the first call were caused by waste on process handling. Four potential factors based on seven wastes were detected. Those factors are: waiting, motion, over-processing, and other. 


\subsubsection{Define Phase}

This phase identified problems coming from customers need which is then followed by deciding which will be the target of improvement. The first step is deciding VOC (Voice Of Customer) which identifies problems. It is found that the majority of problems are connected to high number of customers complaints received by the call center. Complaints included: extensive on-call-waiting for answers, high frequency of unconnectability to call center due to busy line, unsatisfactory of call center service. The second step is deciding VOB (Voice Of Business) which was identified as: management intention to improve call center service quality in order to avoid lost of customer. The third one is creating SIPOC diagram as shown in Table 2 that was analyzed with service blueprint tool.

Table 2 :SIPOC Diagram

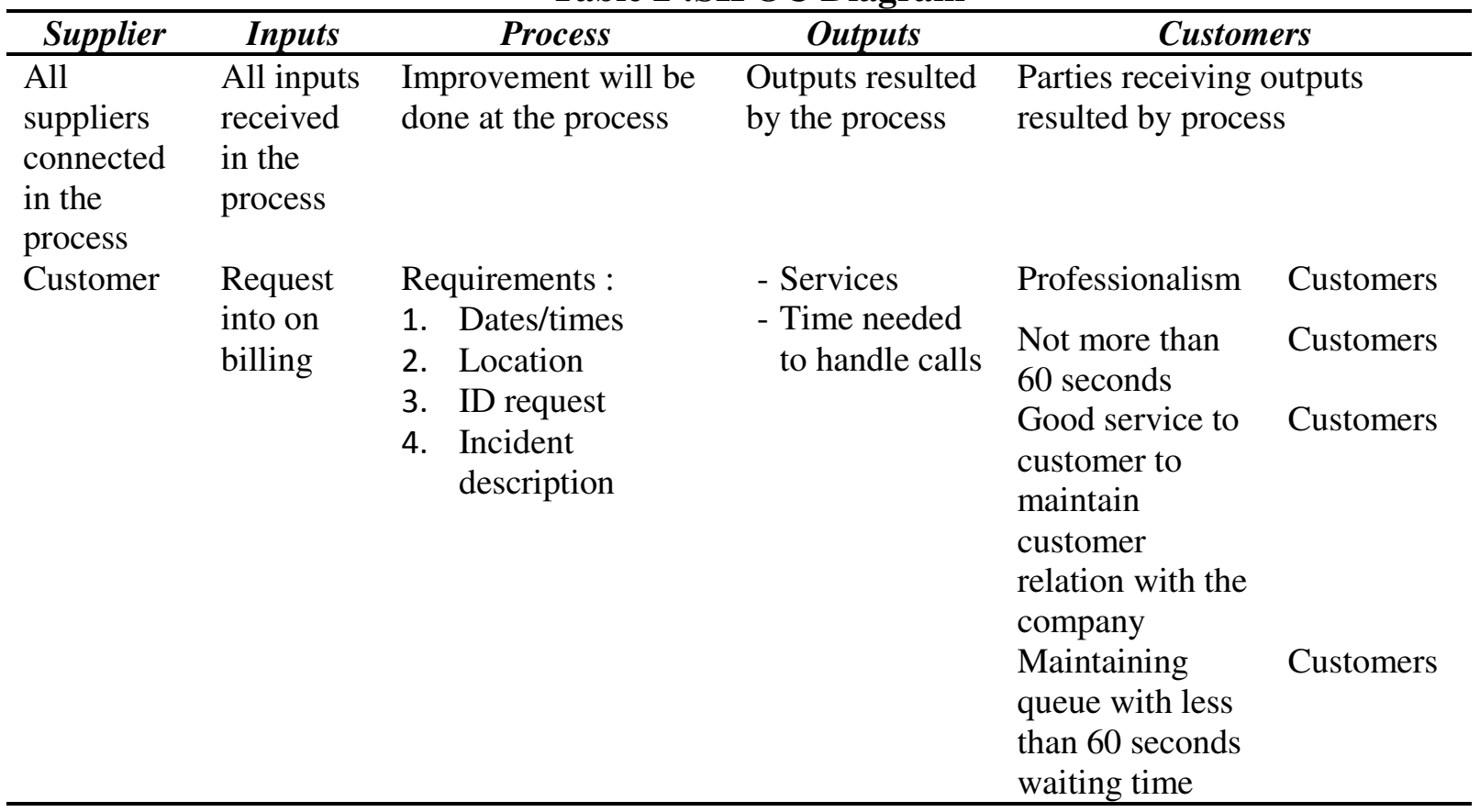

Source : processed

Based on the service blueprint analysis shown inservice blueprint at PT OCI call center (Figure 1), waste happened between point 2 to point 3, when call center operator at the 4th floor was checking availability of on-duty-call doctors at the 3rd floor. Checking had to be done physically by looking in at the doctors lounge whether an on-duty-call doctor was available

\subsubsection{Measurement Phase}

At the measurement phase, the value of DPMO (Defect per Million Opportunities) and the sigma level are measured using a calculated approach

Before DPMO value and sigma level is decided using DPU (Defects Per Unit), DPO (Defects Per Opportunity) and minitab software, an analysis is done using Pareto diagram (Figure 2) to see whether data obtained has great defects and whether it will influence other data.

Based on the data of service quality defect of Table 1 above, there was an occurance of waste in the process of handling the first call which are: motion, waiting, over-processing, and others. Table 2 below shows those defects. Next, data in Table 3 was analyzed with a Pareto diagram to identified the CTQ (Critical To Quality). Figure 2 shows the result of the Pareto diagram. 
Table 3: Amount of Service Quality Defect

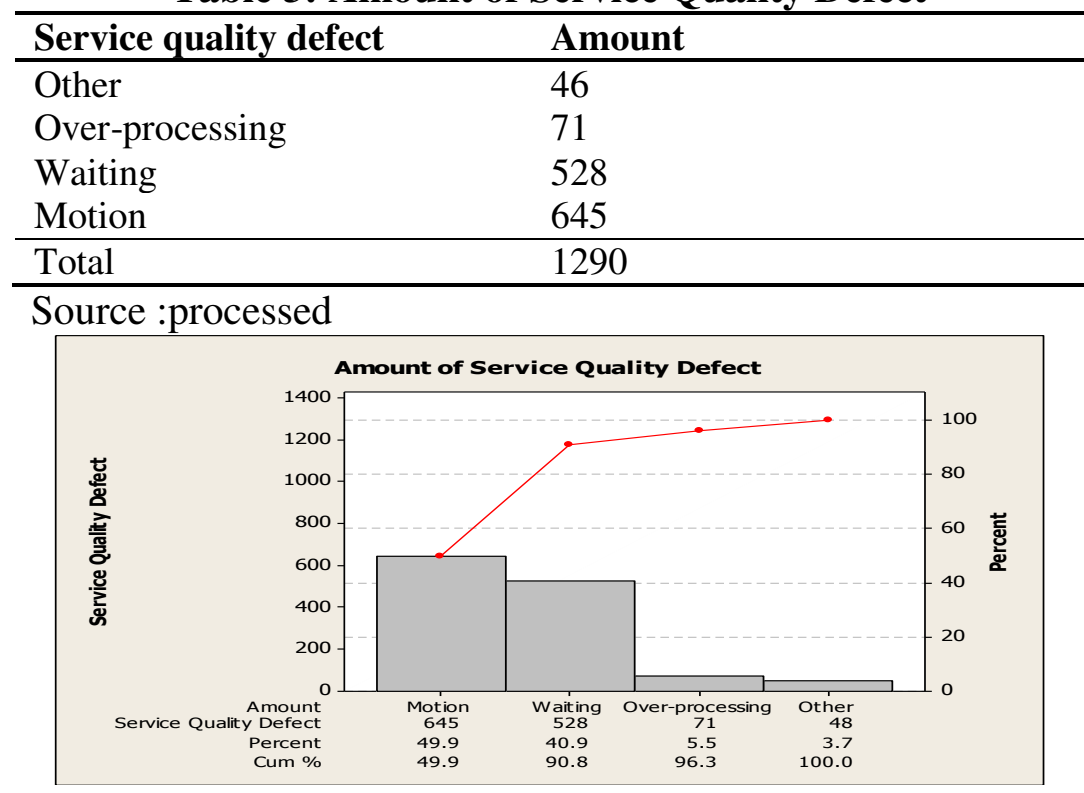

Figure 2 : Pareto diagram

Based on the Pareto diagram, the most probable CTQ could be identified. In this case the potential factor identified are motion and waiting with amount 1173. The DPMO and sigma level were then calculated:

\section{Call Center Service Quality}

$$
\begin{aligned}
& \mathrm{DPU}=\frac{\text { total number of quality service defect }}{\text { total number of unit }}=\frac{1173}{3000}=0.391 \\
& \mathrm{DPO}=\frac{\text { total number of quality service defect }}{\text { defect probability }}=\frac{1173}{(3000 \times 1290)}=0.000303
\end{aligned}
$$

$$
\mathrm{DPMO}=0.000303 \times 1.000 .000=303
$$

The sigma level is obtained by converting the DPMO value to DPMO table of the six sigma (Attachment). The sigma level $\left(\mathrm{Z}_{\mathrm{st}}\right)$ obtained are 4.93 .

\subsubsection{Analyze Phase}

In this phase the vital factor is decided through the potential factor by using two proportion test to see the difference between two different conditions. Based on the pareto diagram, CTQ potential factor would later inform what are to be improved on the next phase, which were the motion and waiting.

Vital factor resulted from service quality defect analysis (Y) was motion (X1) and waiting (X2). From this relation, it is stipulated that

$$
\mathrm{Y}=\mathrm{X} 1+\mathrm{X} 2
$$

Then, an analysis using two proportion test was conducted using minitab software on the motion and waiting. Table 4 and 5 show this step. 
Table 4 : Motion

\begin{tabular}{llll}
\hline & Defect & Ok & Y \\
\hline Idle & 10 & 1280 & 1290 \\
& & & \\
Moving & 645 & 645 & 1290 \\
\hline Source : processed & & &
\end{tabular}

Result of two proportion test using minitab software :

Difference $=\mathrm{p}(1)-\mathrm{p}(2)$; Estimate for difference $=-0,492248 ; 95 \%$ CI for difference : $(-0,519950 ;-0,464547) ; Z=-34,83 ; \mathrm{P}-$ Value $=0,000$

Based on the above result and because the P-Value is $<0.05$, therefore Ho is rejected. This means that with a trust level of $95 \%$, it is concluded that proportion between defect and non-defect motion in idle and in moving forms are different.

Table 5 : Waiting

\begin{tabular}{llll}
\hline & Defect & Ok & Y \\
\hline Quick Respons & 15 & 1275 & 1290 \\
Waiting & 528 & 762 & 1290 \\
\hline Source : processed & & &
\end{tabular}

Result of the two proportion test using mini tabsoftware :

Difference $=\mathrm{p}(1)-\mathrm{p}(2) ; \quad$ Estimate for difference $=-0,397674 ; 95 \%$ CI for difference : $(-0,425137 ;-0,370212)$; Test for difference $=0($ vs not $=0) ;$ P-Value $=0,000$

Based on the above result and because P-Value $<0.05$, therefore Ho is rejected. This means that with a trust level of $95 \%$, it is concluded that the proportion of defect and nondefect at waiting in quick response condition different from the moving condition.

\subsubsection{Improvement Phase}

At this phase, improvement is done with lean methods using seven wastes and DOE (Design Of Experiment) approach. The seven waste approach is needed to see whether unecessary steps in the process existed which was extravagant from theseven waste method point of view. Based on the seven waste, waiting and motion had occured. In waiting, customers spent extensively long time to obtain confirmation for a call center. In motion, a lot of call center operators in 4th floor moved about to find out the availability of on-duty-call doctors at 3 rd floor.

Based on the analysis obtained at the analysis phase, improvement needed to be done. Firstly was for motion, operators must not move out from their work station for task beyond their responsibilities except for personal reasons (going to the restroom, official break, doing prayers, on condition that back up operators are available). Secondly was for waiting, operators must comprehend and understand questions raised by customers. Trainings could be given to all operators, to minimize this problem, a controlling tool was created to know the availability of on-duty-call doctors in the 3rd floor. This tool funcitons electronically with indicator lamps signaling whether there is or there isn't an on-duty-call doctor. Figure 3 shows that tool. 


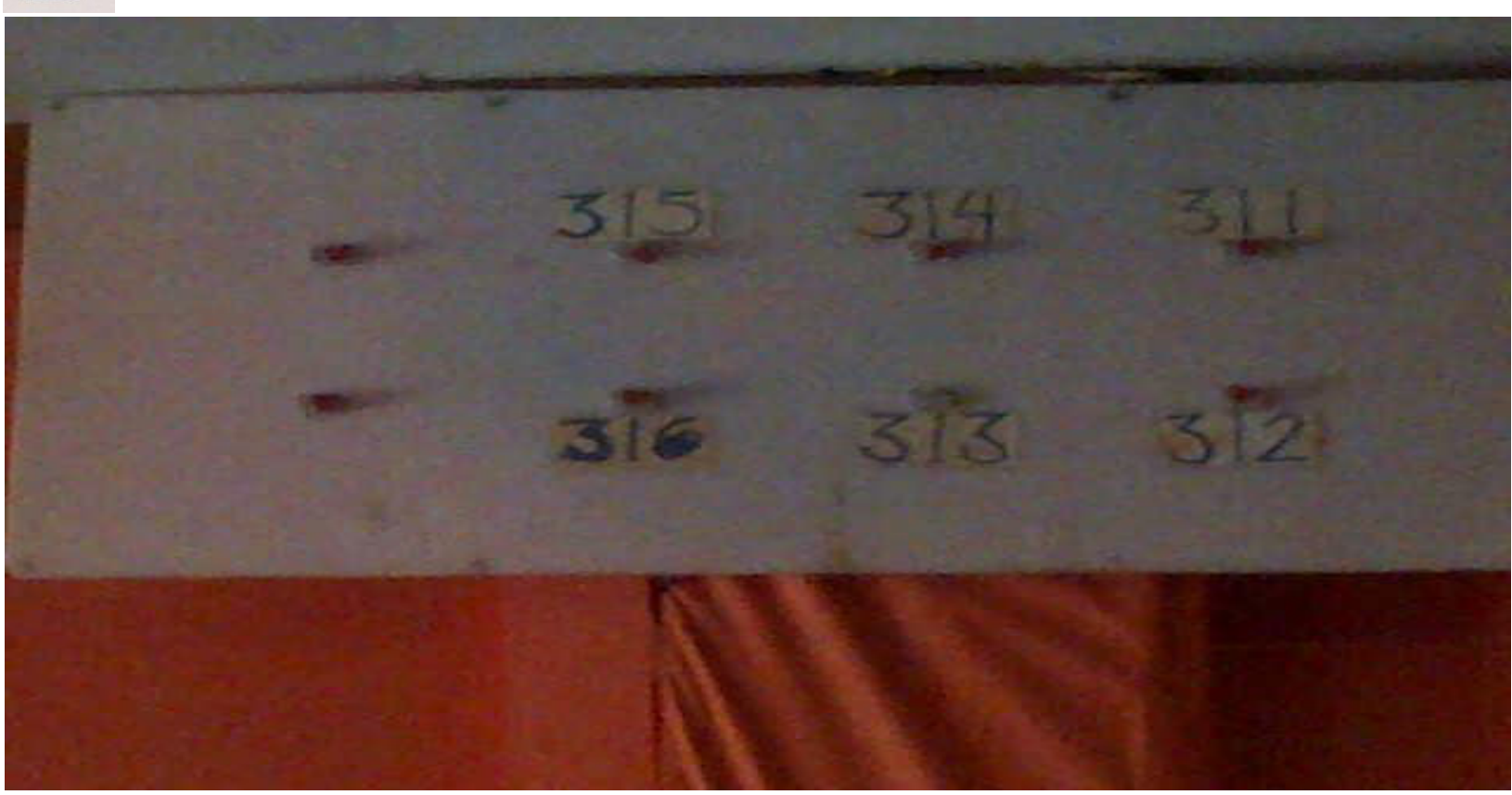

Figure 3: PT OC call center control tool for on-call-duty doctor

At each improvement stage, improvement is implemented through DOE which is a tool to show preliminary decision on data collecting from the experiment and data analysis in order to obtain accurate information of the experiment.

An experiment of service quality of the call center is done where, variable X1and X2 are the vital factors of :

$$
\begin{aligned}
& X 1=\text { motion } \\
& X 2=\text { waiting }
\end{aligned}
$$

Next, a DOE (design of experiment) is created to see the result when $\mathrm{X} 1$ and $\mathrm{X} 2$ are combined. The result could be a similarity or difference. The result is the value of $Y$ in form of service quality as shown in Table 6 . With the aid of the Minitab software, a cube plot graph is then created (as shown in Figure 4) to obtain cube plot calculation, optimum value is a combination of motion $=$ concentration and waiting $=60$ second which is $=1$.

Table 6: DOE of call center service quality defects

\begin{tabular}{lllllll}
\hline StdOrder & RunOrder & CenterPt & Blocks & Motion & $\begin{array}{l}\text { Waiting } \\
\text { (in seconds) }\end{array}$ & $\begin{array}{l}\text { Y } \\
\text { (service } \\
\text { quality) }\end{array}$ \\
\hline 1 & 1 & 1 & 1 & Concentration & 60 & 4 \\
2 & 2 & 1 & 1 & $\begin{array}{l}\text { Moving to } 3^{\text {rd }} \\
\text { floor }\end{array}$ & 60 & 3 \\
3 & 3 & 1 & 1 & $\begin{array}{l}\text { Concentration } \\
180\end{array}$ & 2 \\
4 & 4 & 1 & 1 & $\begin{array}{l}\text { Moving to } 3^{\text {rd }} \\
\text { floor }\end{array}$ & & 180 \\
\hline
\end{tabular}




\begin{tabular}{lllllll}
\hline 5 & 5 & 1 & 1 & Concentration 60 & 4 \\
6 & 6 & 1 & 1 & $\begin{array}{l}\text { Moving to } 3^{\text {rd }} \\
\text { floor }\end{array}$ & 3 \\
7 & 7 & 1 & 1 & $\begin{array}{l}\text { Concentration } \\
8\end{array}$ & 180 & 2 \\
8 & 8 & 1 & 1 & $\begin{array}{l}\text { Moving to } 3^{\text {rd }} \\
\text { floor }\end{array}$ & 180 \\
\hline
\end{tabular}

Source : processed

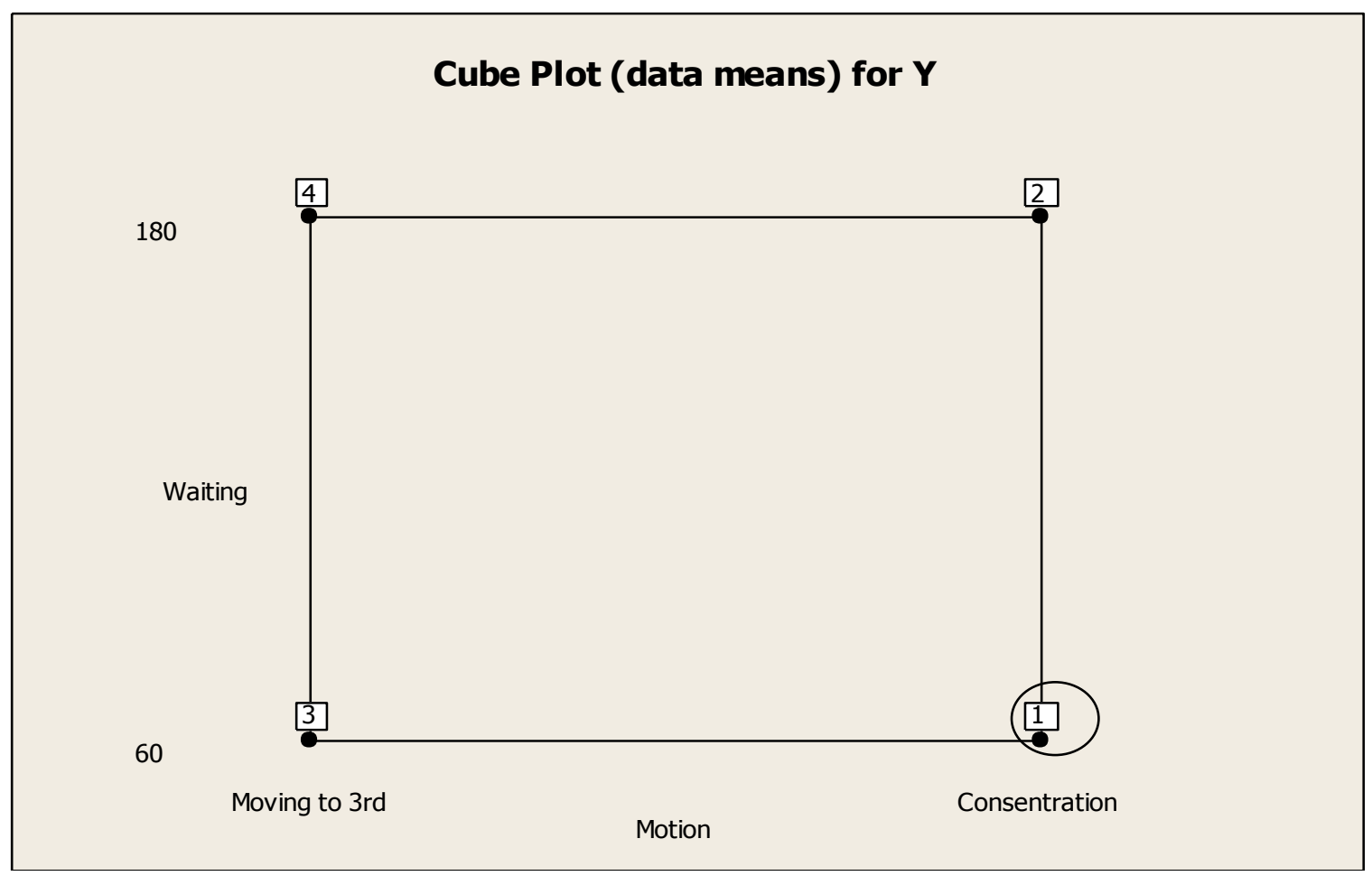

Figure 4 : Cube Plot Of Data Y Average

After improvement phase, the total number of quality service defect for motion and waiting are 61 and DPMO and sigma level final after improvement to call center service quality was implemented is as follows:

$$
\begin{aligned}
& \mathrm{DPU}=\frac{\text { total number of quality service defect }}{\text { total number of unit }}=\frac{61}{3000}=0.0203 \\
& \mathrm{DPO}=\frac{\text { total number of quality service defect }}{\text { defect probability }}=\frac{61}{(3000 \times 179)}=0.0001136 \\
& \mathrm{DPMO}=0.0001136 \times 1.000 .000=113,604
\end{aligned}
$$

The value of sigma level is obtained by converting DPMO value to the DPMO table of the six sigma. Sigma level $\left(\mathrm{Z}_{\mathrm{st}}\right)$ obtained is 5.20 


\subsubsection{Control Phase}

After improvements were made, call center service quality is standardized in control phase.At this stage controlling activities are performed, based on the data in Table 7, and control activities using p-chart tools whose purpose is to stabilize optimum improvement as well as to plan controlling activities using the p-chart tool. Using the minitab software, the pchart results for post improvement on call center service quality (Table 7) are shown in Figure 5 .

Table7: Post improvement on call center service quality

\begin{tabular}{ccc}
\hline Motion & Waiting & Y=X1 + X2 \\
\hline 2 & 3 & 5 \\
5 & 3 & 8 \\
2 & 6 & 8 \\
4 & 6 & 10 \\
2 & 3 & 5 \\
5 & 3 & 8 \\
2 & 6 & 8 \\
3 & 6 & 9 \\
& & $\sum \mathrm{Y}=61$ \\
\hline
\end{tabular}

Source : processed

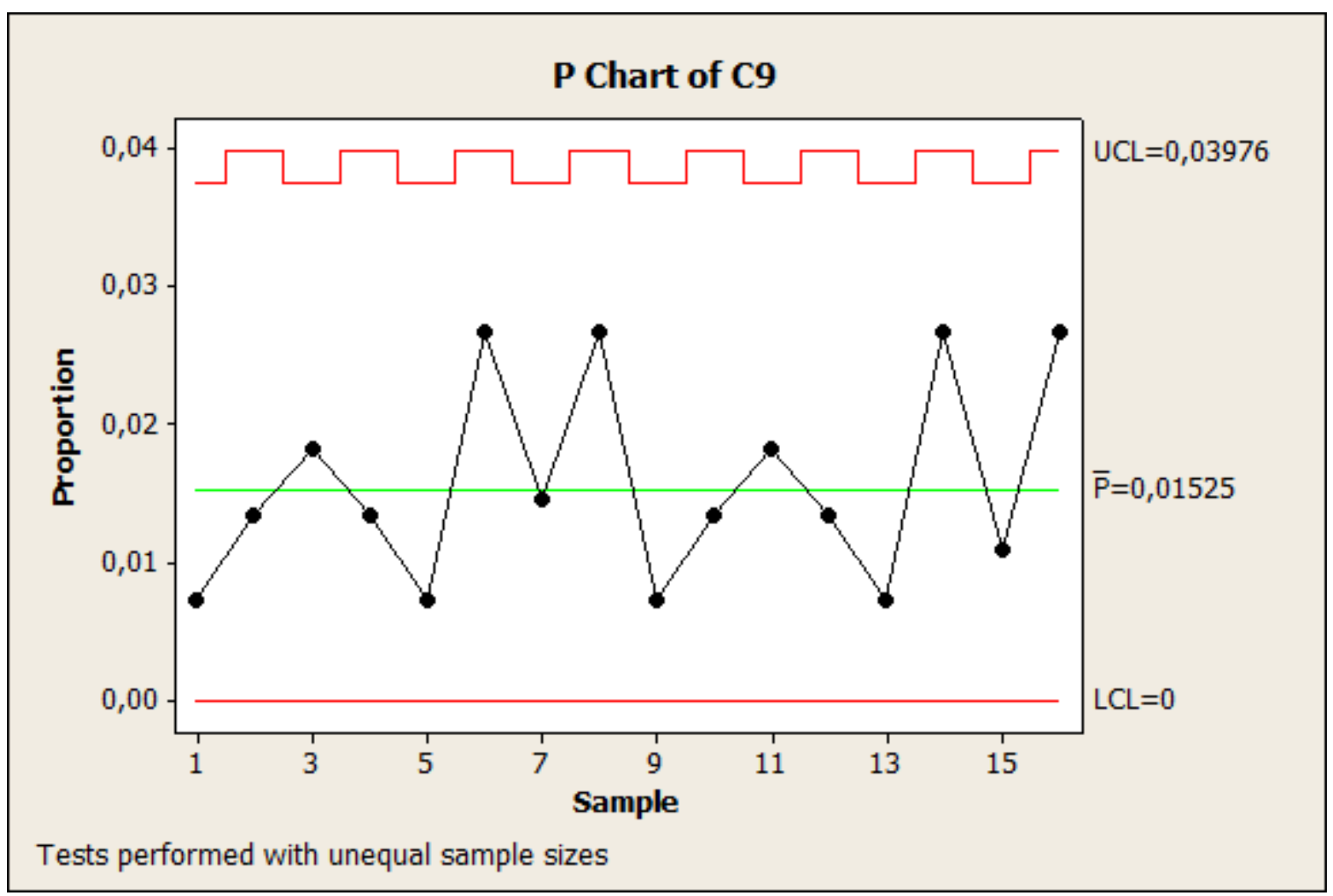

Figure 5 : p-chart of call center service quality

\subsection{The Processes of Service Improve}

The process of call center services PT OCI that is visible during service blueprint , a groove relation of point 2 to a point 3 to a point 4 show problem that happens. Then at a groove was done improving service quality by using the method DMAIC, to get the best sigma level.

Based on Figure 1 and the end of the sigma level obtained, improving service quality of call center at PT OCI is on a communication between call center operators at PT OCI (point 2 and 4) with a doctor at PT OCI (point 3). Communication between call center operators with a doctor before improving service quality are calling a doctor up to the doctor room to know the 
doctor readiness, this has resulted in the waiting time for customer to get the information. Then after done improvements, communication between call center operators with a doctor is by seeing indicators about readiness a doctor at PT OCI through this device, as shown in Figure 3 , if in the doctor room there are doctors who are ready to serve, then the lights will turn on.

\section{Conclusion}

The The analysis and discussion of "DMAIC method" and "service blueprint" implementation showed that there is an interrelation between service quality improvement and the process of service, point of contact with customers and evidences of service seen by customers. Improvement could be applied with "DMAIC method" with lean approach. The "DMAIC methodology" using "lean" approach aims to identify waste and "service blue print"enables to shorten service process by eliminating unnecessary operation in the service process and point of contact with customers. The five stages of DMAIC (define, measurement, analysis, improvement, and control) increased service quality of PT OCI call center, and it reduced loss derivating from unsatisfied customers who withdraw their loyalty when they experienced bad services.

The achievment of reaching objective in increasing call center quality,has created better services. This is shown by the final sigma value at the stage of after the implementation of improvements. The final sigma level became 5.20from the previous 4.93. "DMAIC method" using lean approach and service blueprint could be applied in the service sector using call center service. By looking at the sigma level, service quality is clearly seen to have implication in form of change of customers satisfaction.

\section{References}

Antony, J., Bhuller, A. S., Kumar, M., Mendibil, K. \& Montgomery, D. C. (2012). Application of Six Sigma DMAIC methodology in a transactional environment, 29(1), 31-53. https://doi.org/10.1108/02656711211190864

Atkinson, P. (2014). DMAIC : A Methodology for Lean Six Sigma business transformation. Management Service, 58 (1), 12-17.

Chase, R., B., Jacobs, F., R., Aquiland, N., J. (2004). Operations Management for Competitive Advantage. Tenth Edition, New York, The McGraw-Hill Companies, Inc.

Debusk, G., K. \& Debusk, C. (2010). Characteristics of Successful Lean Six Sigma Organizations, Cost Management, 24 (1), 5-10.

Souza, R. P. de, He, R., Oliveira, B., Queiroz, J. V., \& Ambro, L. (2013). Implementation of a Six Sigma project in a 3M division of Brazil, 30(2), 129-141. https://doi.org/10.1108/02656711311293553

Dreachslin, J., L., Lee, P., D. (2007). Applying Six Sigma and DMAIC to Diversity Initiatives, Journal of Healthcare Management, 52 (6), 361-367.

Gaspersz, V. (2007). Sistem Manajemen Kinerja Terintegrasi: Balanced Scorecard Dengan Six Sigma Untuk Organisasi Bisnis Dan Pemerintahan. Cetakan Keempat, Jakarta, PT. Grademia Pustaka Utama.

George, M., L. (2003). Lean Six Sigma foe Service: How to Use Lean Speed and Six Sigma Quality to Improve Services and Transactios. New York, McGraw-Hill.

Jayaraman, K. (2010). Value Stream Mapping-Adapting Lean Management Principle in the ESO. Integrated Engineering Service (IES). Retrieved from http://www.inttechservices.com/media/28549/value-stream-mapping-adapting-leanmanagement-principle-in-the-eso.pdf.

Kumar, S., Strandlund, E., \& Thomas, D. (2008). Improved service system design using Six Sigma DMAIC for a major US consumer electronics and appliance retailer, International 
Journal of Retail \& Distribution Management, 36(12), 970-994. https://doi.org/10.1108/09590550810919388

Laureani, A. (2011). Lean Six Sigma in Service Industry. Advanced Topics in Applied Operations Management. Retrieved from http://www.intechopen.com/books/advancedtopics-in-applied-operations-management/lean-six-sigma-in-theservice-industry.

Laureani, A., Antony, J., \& Douglas, A. (2010). Lean six sigma in a call centre: a case study. International Journal of Productivity and Performance Management, 59(8), 757-768. https://doi.org/10.1108/17410401011089454

Liker, J., K. (2004). The Toyota Way 14 Prinsip Manajemen dari Perusahaan Manufaktur Terhebat di Dunia, Jakarta, Penerbit Erlangga.

Mcadam, R., Davies, J., Keogh, B., \& Finnegan, A. (2009). Customer-orientated Six Sigma in call centre performance measurement, International Journal of Quality \& Reliability Management, 26(6), 516-545. https://doi.org/10.1108/02656710910966110

Nakhai, B.\& Neves J., S. (2009). The challenges of six sigma in improving service quality, International Journal of Quality \& Reliability Management, 26(7), 663-684. https://doi.org/10.1108/02656710910975741

Reisenberger, C. \& Sousa, S., D. (2010). Application of the Six Sigma Methodology in Customer Complaints Management : A Case Study in Automotive Industry, POMS 21st Annual Conference, (pp. 1-22), Vancouver, Canada. 